\title{
Cottage Resort Simalem Park (Traditionalism)
}

\author{
Firman Eddy ${ }^{I^{*}}$, Rini Oktarine $S^{1}$
}

${ }^{1}$ Architecture Departement, Faculty of Engineering, Universitas Sumatera Utara, Medan, Indonesia.

\begin{abstract}
Tourism will be producing foreign exchange in Indonesia. Indonesia has a tourism appeal that manifests itself in traditional homes and village. In promoting Indonesian tourism to foreign countries, traditional architecture is a better choice, but fewer relics of traditional building art are worth a visit. Sumatera is an ethnically diverse island. Sumatera has become a tourist attraction that is often visited by foreign tourist. Resort attractions are becoming tourist attractions and lodging that is frequented by foreign tourist. There are several problems, namely how to realize the planning and design of resort cottages by considering traditional architecture and having planning standards that need to consider based on comparative studies carried out, then how to process the appearance of the building to fit the atmosphere in Taman Simalem Resort. With the aim of the design is to realize the concept of designing Resort Cottages and supporting facilities such as restaurants and spas by applying the principles of Traditional architecture. The design method used in the object design includes two aspects, namely the approach to the design theme, location, and environmental studies.
\end{abstract}

Keyword: architecture, cottage, resort, traditionalism.

\section{Introduction}

Indonesia is a country that has a tropical climate. A country is famous for its abundant natural wealth. In some areas there are also many natural forests and beautiful natural view, so the air and air are colled and protected from pollution. In north Sumatera, many inns provide with facilities surrounding natural scenery is still beautiful. Lodging provides a cottage resort.

Cottage resort is a kind of accommodation located around the beach or lake with the form of separate buildings. Cottage resorts with natural scenery provide visual comfort for tourists. The design object is a lodging house in the form of a collection of cottages that have the main facilities of a bedroom, sitting room, bathroom, dining room, kitchen, and terrace. Available also other supporting recreational facilities, and supported by a natural atmosphere of the river and surrounding forests that can meet the needs of visitors and foreign tourist. The history of

\footnotetext{
*Corresponding author at: Department of Architecture, Faculty of Engineering, Universitas Sumatera Utara, Jalan Perpustakaan Gedung J07, Medan 20155, Indonesia

E-mail address: rechvidimaz@yahoo.com
} 
traditional architectural action is closely related to the history of nationality and culture, so it has a very high value.

\section{Literature Review}

\section{Location and Site}

The project location of Cottage Resort Simalem Park is located in Merek. Merek is one of the subdistricts of 17 towns located in Karo district. This district is plateau in the high of Karo, the hill of North Sumatra. Located 77 kilometers from the city of Medan. The number of Simalem Park visitors each year reached 14,242 tourists (Figure 1).

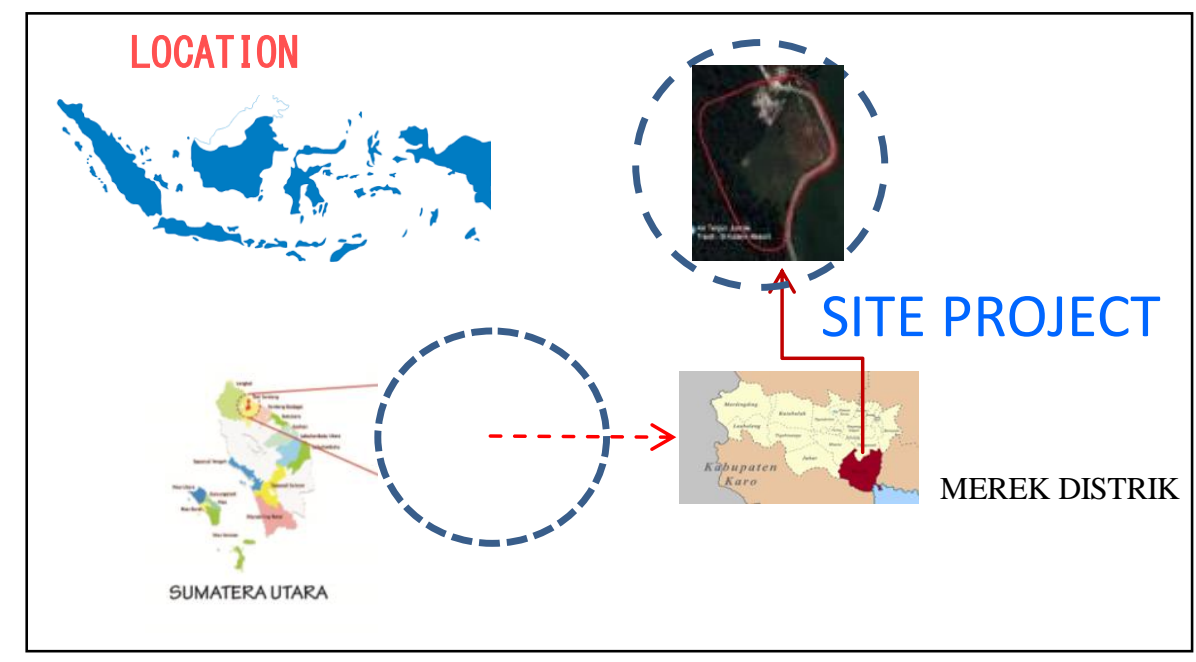

Figure 1. Project Location

\section{Theme Review}

According to Amos Rapoport (1960), traditional architecture is a form of architecture that passes from one generation to the next. Studying traditional buildings means learning the traditions of the people. The traditional house is the cultural identity of one ethnic group because it contains all the life of society [1]. The history of traditional architectural action is closely related to the history of nationality and culture, so it has a very high value that needs to preserve the existence of existing and does not change its trademark. Thus, traditional architecture shows human relationships with its history in the field of buildings and settlements. The traditional village form reflects a harmonious, original, rhythmic and dynamic way of life that is no longer in the new village. Although this ancient way we often cannot understand it anymore. But we can not raise the past.

\section{Comparative Study}

Samosir Villa Resort is a villain Tuk-Tuk, Samosir. The elegant design of the resort envelops villas, cottages, restaurants, swimming pools, playgrounds. Samosir Villa Resort is designed using traditional Batak roof and some Batak ornaments on the building wall (Figure 2). 


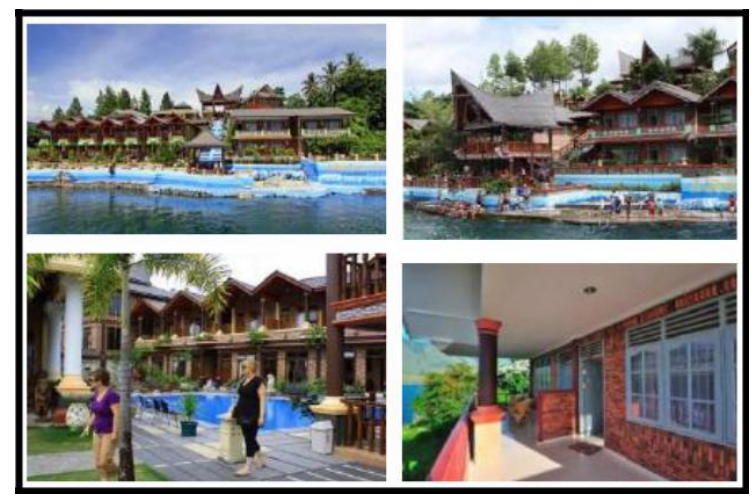

Figure 2. Samosir Villa Resort

(Source: http://www.samosirvillaresort.com, 2018)

Maya Resort Ubud is a five-star resort with a combination of modern and traditional concepts located in the city of Ubud, Bali. Maya Resort Ubud borders by the valley of Penate Timur River and green paddy fields visible from the west side. Modern Balinese style reflects on the use of thatched roofs. Maya Ubud Resort award by Green Globe (2012-2013) (Figure 3).
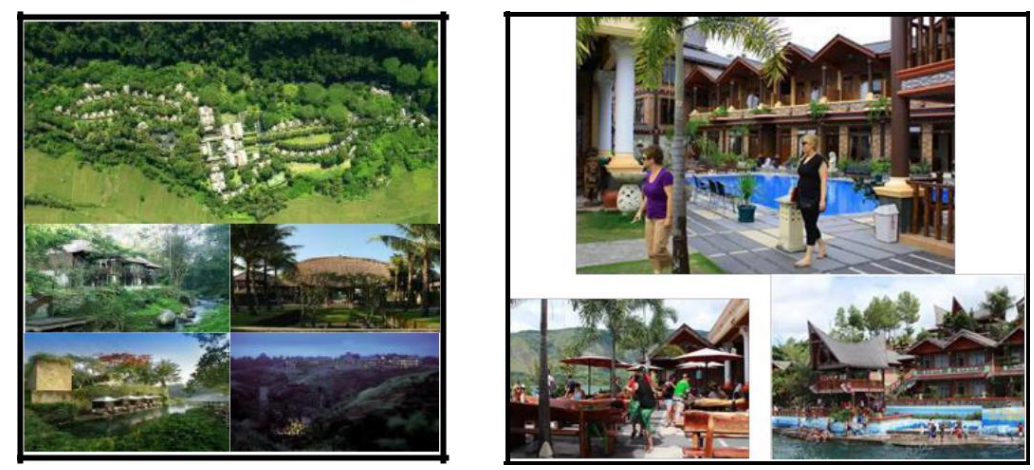

Figure 3. Maya Resort Ubud

(Source : http://www.mayaresorts.com, 2018)

Natura design is designed to enhance the beauty of the atmosphere. Preservation of existing vegetation and protection of rivers and wildlife is essential in design. Located within the Petanu River valley, one of Bali's sacred rivers, the emphasis is on the nature of rivers and forests. With direct access to a clean natural pool and a soothing sound from continuously running water, it utilizes as a spa supporting object that can enhance comfort while in the spa area. The forest site is a plateau with dramatic scenery along the river, already rich and dense with native trees found in the forest. The abundant natural springs provide peace for tourists (Figure 4). 


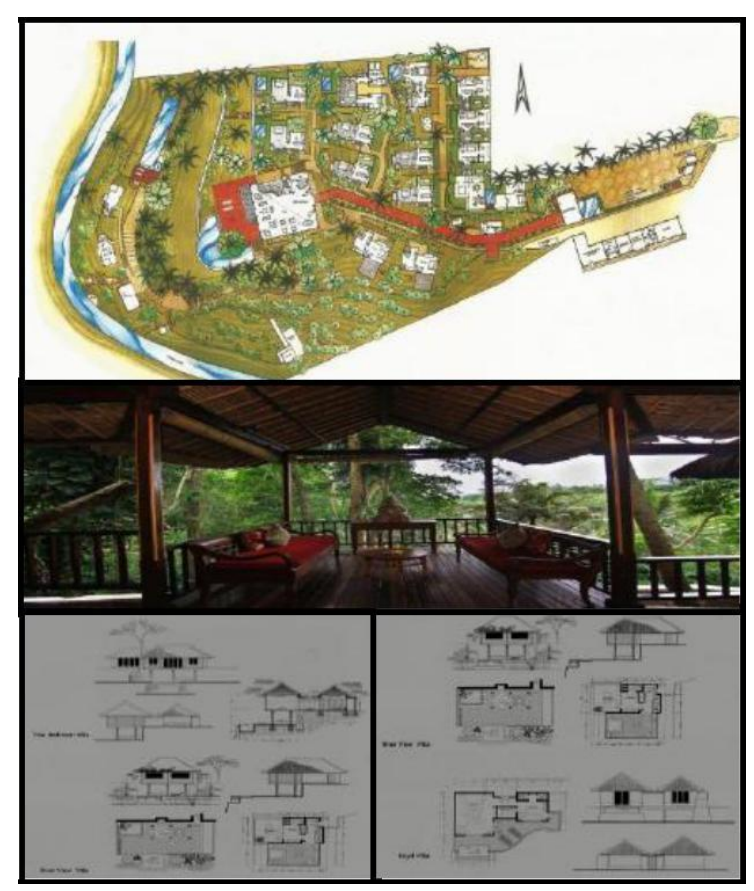

Figure 4. Natura Resort and Spa

(Source: https://www.naturaresortbali.com/gallery.html, 2018)

In the design of this project, Popo is successful in overcoming the problems of an extreme topography by creating a building that is adaptive to its site. Moreover, the involvement of local community in the process provides a positive contribution towards building a model for developing and design tourism facilities [2]. Comparative study of all resorts can see that the resort is more utilizing the ambiance of the surrounding environment is still natural. Each villa and cottage has several forming elements that introduce each culture. Landscape arrangements that follow the contours of the soil provide a natural and eco-friendly impression.

\section{Methodology}

The design method used is two aspects of the approach to the theme of design and approach to the assessment of the site and the environment. The theme studies of Traditionalism use these processes and influence the results, both in site analysis and functional analysis. Stages of processing data on the characteristic Traditionalism on the site using literature study of the literature and also data that exist on the internet.

\section{Result and Discussion}

In mass, cottages will use the same roof formation with each custom house. On the walls of the building will use a glass material combined with wood material that serves as a column in the building. Circulation paths inside the site divide into three, namely pedestrian paths, bicycle lanes, and vehicle lanes. The concept of vehicle user circulation when heading to the parking area is linear circulation. A straight path can be an organizing element for a row of space [3]. The concept of bicycle user circulation within the site is the circulation around the building and 
the site area. To distinguish the circulation, material processing, ground treatment and use limiting elements (vegetation). The concept of pedestrian circulation in the location uses irregular 2-way circulation. This idea can make people interested in looking at each other and greeting each other. The building structure on the site is a facing direction facing the building consisting of 3 types namely one room, two rooms, and three rooms. Preparation of building mass arrangements by using a combination of cluster patterns and irregular. Based on the following noise and circulation analysis is the concept of laying the zone on the tread, public zone place in so that it is affordable for visitors coming from the parking lot or from outside the site. The private zone is further away from noise. Homestay tourists place in a private area. Circulation can only achieve by tourists and employees.

The structural system of the 3-story main resort building utilizes traditional to modern roof applications. Roof frames using wooden structures and roof coverings already use clay tile. The walls of buildings still use wooden structures combined with a glass material, so the buildings still have a natural feel. In the cottage building using the same structure system with the traditional house building. A roof that uses wooden roof truss in expose into the room. The column columns serve as the second-floor load carrier to the foundation. The transformation of traditional architecture deals with functions, structures, and architectural elements to create a new form (Figure 5).

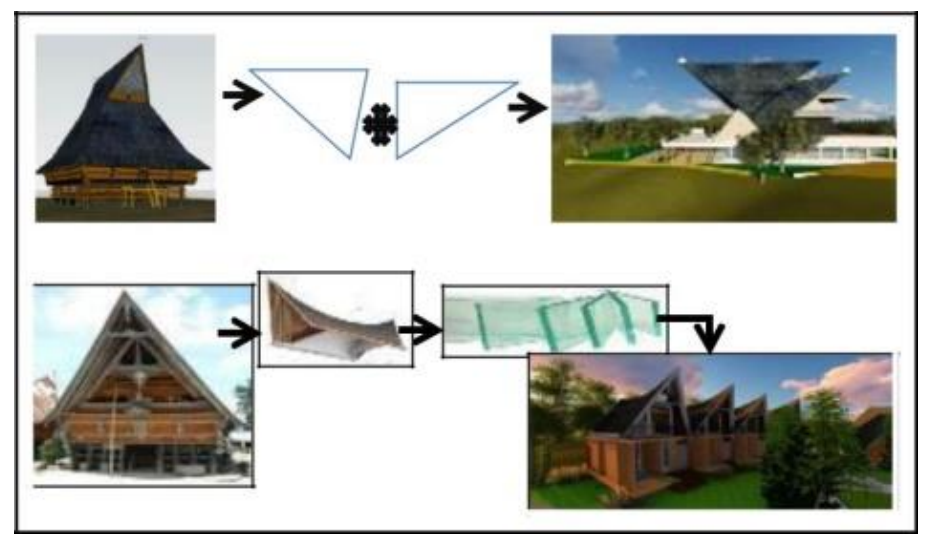

Figure 5. The Concept of Mass and Facade

Based on the analysis of the completion of the concept, the material used is the same material with the original condition of the atmosphere to be created. Such as wood brick and stone rocks exposed. Reinforced concrete construction is an option in structural design (Figure 6). The landscape is arranged by following contours so that the arrangement is more natural (Figure 7). 


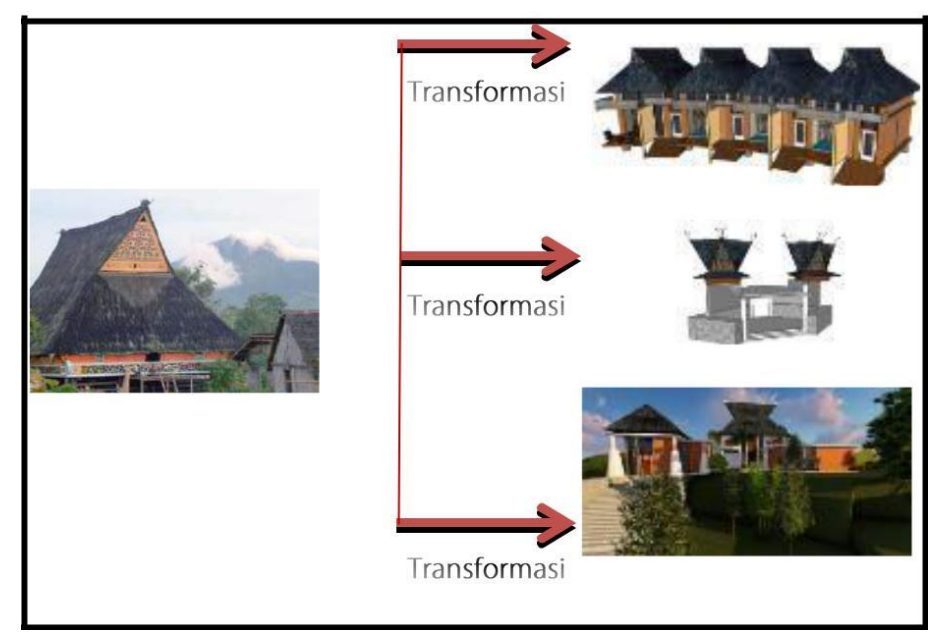

Figure 6. The Concept of Mass and Facade

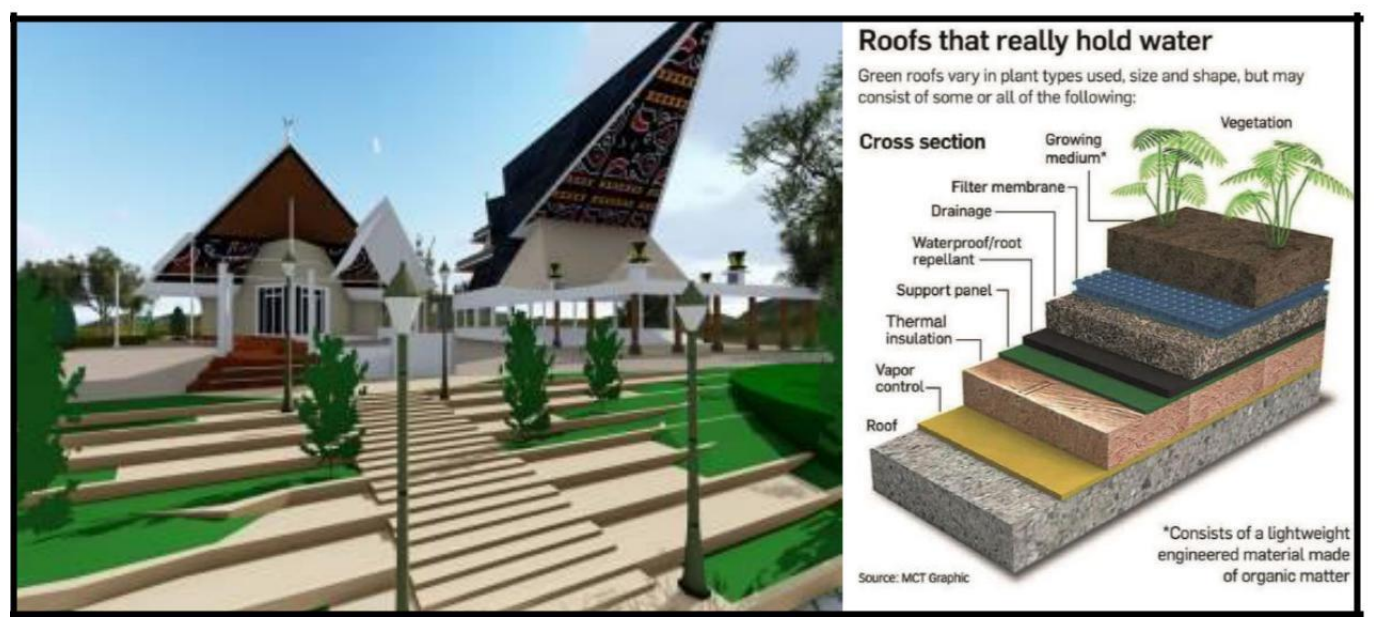

Figure 7. The Concept of Landscape

\section{The Concept of Lighting and Natural Worship}

Column Wall

On the 1 st floor of the wall of the coffee shop and cottages, the building uses more concrete columns. So that sunlight can enter the building, but air from the river can also enter through the cracks of the column (Figure 8).

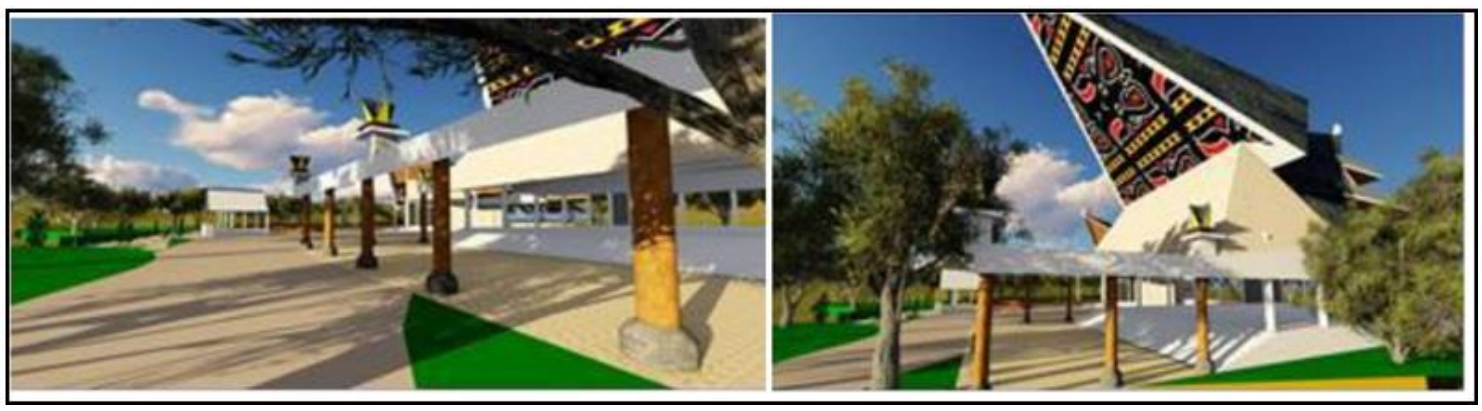

Figure 8. Column Wall 


\section{Glass wall}

The walls on the Coffee Shop building on the 2nd-floor use glass material that has lowemissivity technology that is transparent. So that sunlight can enter but reduce heat from the sun's light (Figure 9).

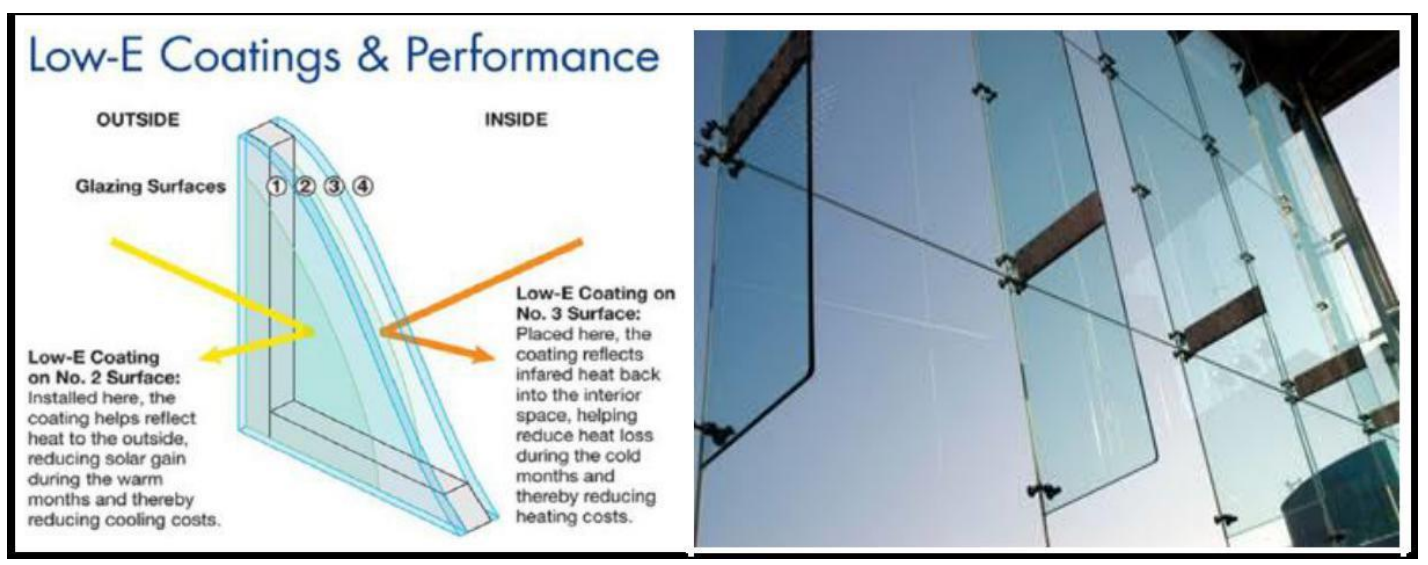

Figure 9. Glass Wall

\section{Sun Light Buffer}

The concept Sunlight must filter first so that the light does not go directly into the room which can cause the room temperature to heat up. The filtering of sunlight is carried out by providing vegetation around the building and applying an overhang as a light reflection (Figure 10).

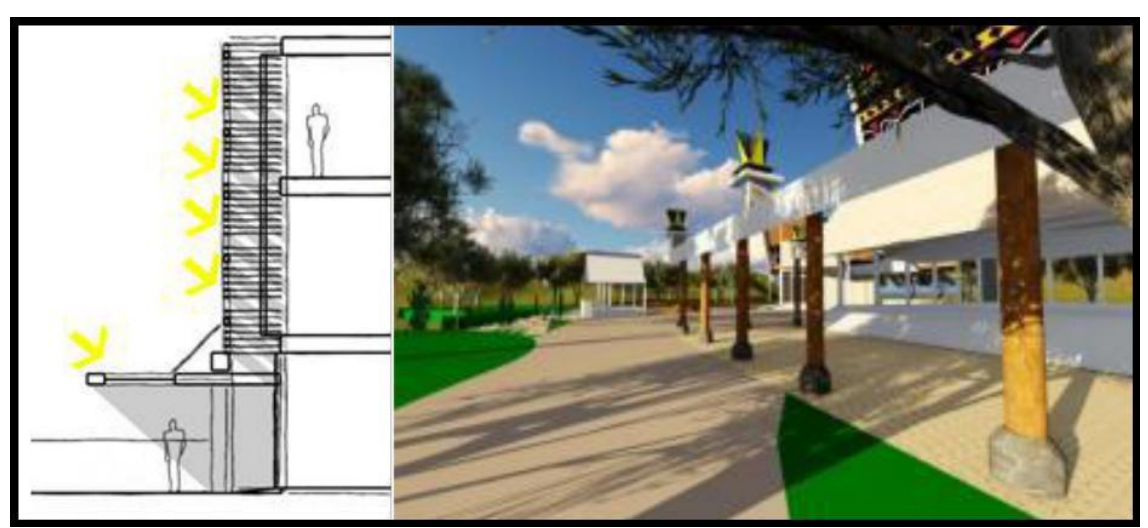

Figure 10. Sun Light Buffer

\section{Universal Design Implementation Concept}

This concept applies the ramp path to the design to facilitate travel for people with disabilities. A Ramp can use by everyone, but there are still stairs available for other users. The ramp applied to the coffee shop building design for bay cars that are used as visitors transportation to the second floor of the building (Figure 11). 


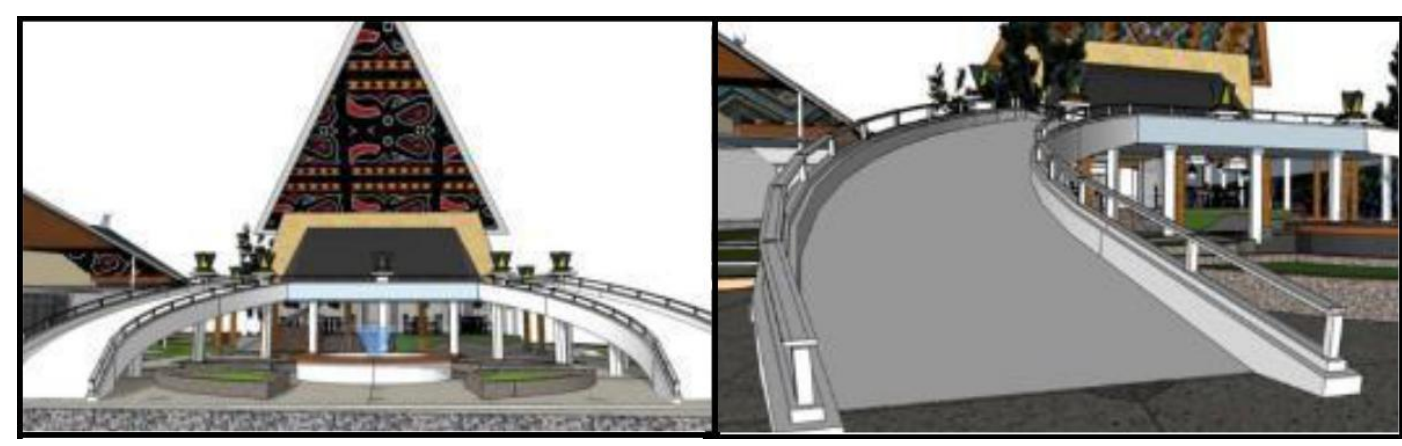

Figure 11. Concept Ramp

\section{Transportation Concept}

In this design, the transportation system uses the car which is the main transportation to take visitors to the cottage cluster or other facilities. This design also provides bicycle lending facilities that can be used by visitors to surround the site or browse the design atmosphere (Figure 12).

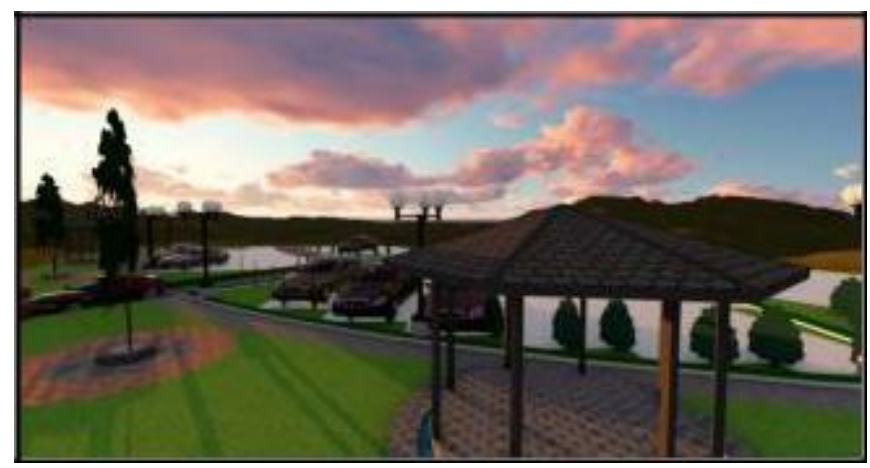

Figure 12. Parking Area

\section{Conclusion}

Cottage Resort is expected to become a new tourism place in the city of Medan that introduces various ethnic groups in Sumatra. In the design that remains to take advantage of natural nuances contained in Sumatra. The cottage is a space that provides temporary residence as well as objects to introduce custom house form in Sumatra. The structure of the building will combine with modern architecture and materials made similar to natural materials. Natural aesthetics provides a visual sense for visitors.

\section{Acknowledgment}

The researchers has prepared this article and was partly funded by the Department of Architecture Universitas Sumatera Utara a contribution for the city government in planning and design to maintain existing local wisdom. 


\section{REFERENCES}

[1] S. Myrta, Dari Arsitektur Tradisional Menuju Arsitektur Indonesia, Jakarta: Ghalia Indonesia, 2003.

[2] T. Achmad dan A. Yori, The Long Road Towards Recognition: Select Word of Indonesian Architects, Jakarta: Gramedia Pustaka Utama, 2005.

[3] D. C. Francis, Arsitektur: Bentuk, Ruang dan Tatanan, Jakarta: Erlangga, 2000. 